\title{
LIFE SATISFACTION AS INTEGRATIVE PSYCHOLOGICAL PHENOMENON
}

\section{Skripachenko T. V.}

\section{INTRODUCTION}

A number of scientific works have focused on the study of life satisfaction phenomenon. This concept is essential for understanding human nature, happiness, attitude to life and human values.

Life satisfaction is the assessment of the difference between the current state of affairs and the ideal situation, whereas the role of affective evaluation is performed by positive and negative emotions and states, related to daily experiences. M. Selihman and M. Arhaile are the representatives of this field of research. They define life satisfaction as a subjective, cognitive, and reflective assessment, an idea of how prosperous everything has been and remains.

The level of satisfaction with life depends on several factors, but it is not limited to their sum.

Life satisfaction is positively correlated with presence of significant social contacts; assessment of social status as satisfactory, assessment of one's own health as prosperous; the state of necessity for meaningful people; assessment of financial situation as satisfactory; opportunity to express creativity; satisfaction with the process of professional activity; vision of own prospects; free time for leisure; autonomy as the ability to act according to one's beliefs; personal growth as an opportunity to progress in all areas of life and matrimony ${ }^{1}$.

Negative correlating factors include poverty and lack of wealth for living; assessing health as bad and deteriorating; depression; phobic personality disorders; low self-esteem; high level of anxiety and low level of social activity and significance.

Factors with low correlation include age; sex; education; ethnicity; citizenship and country of residence; religion; relevant emotions; IQ; actual wages; profession and position.

The research of life satisfaction is connected with different psychological directions. They are studies of happiness, peculiarities of forming self-esteem, notions of adaptability, stereotypes, standard of living, etc.

\footnotetext{
${ }^{1}$ Аргайл М. Психология счастья. Изд.2-е. Сант-Петербург.: Питер, 2003. 332 с.
} 
According to M.S. Yehorov's, M.A. Sytniykova's and O.V. Parshykov's ${ }^{2}$ research indicators of overall life satisfaction and satisfaction with certain aspects of life such as career and personal relationships are connected. The structure of the parental family does not affect the life satisfaction indicator. Married people are more satisfied with life. However, marital status is not connected with satisfaction with one's personal life and career. Furthermore, among the dispositional traits of the individual extraversion is more related to satisfaction with life in general and with its certain components (personal life and career), and to a lesser extent emotionality, integrity and benevolence.

Sincerity and openness to new experiences are almost insignificant in developing life satisfaction.

An analysis of the phenomenon of life satisfaction can be seen in the context of needs, aspirations and achievements, emotionally-evaluative attitude to yourself and others, "self-concept", self-actualization, happiness and psychological (subjective) welfare, social well-being and subjective assessment of quality of life and health ${ }^{3}$. Satisfaction with life can also be defined as a condition characterized by the fulfillment of one's own actual needs (vital, psychological, physical, social) and conformity with their level of satisfaction with real opportunities, etc.

\section{Psychological factors of life satisfaction}

M. Arhail wrote a comprehensive work which consists of great material of Western European and American happiness researchers. In addition, the factors of happiness are at the same time the sources, conditions, and areas of life satisfaction, and sometimes the characteristics of the subject itself - a set of personality traits that can be identified, measured, and which demonstrate a statistically significant conection with life satisfaction.

From M.Arhail point of view, happiness is a state of experiencing satisfaction with life in general, an overall reflexive assessment of a person's past and present, as well as the frequency and intensity of positive emotions. He also shows the dependence of happiness on social connections. They are important due to the the psychological support which is given to the individual by loved ones. Significant social connections are: marital, intrafamily and close friendly relations.

According to Leontiev D.A., Shamionov R.M. especially important role of emotions and feelings of happiness should be considered along with the concept of life satisfaction.

${ }^{2}$ Егорова М.С., Ситникова М.А., Паршикова О.В. Адаптация Короткого опросника Темной триады. Психологические исследования, 2015, Т. 8. № 43. С. 15-21.

3 Вірна Ж.П. Адаптаційний профіль задоволеності життям особистості. Проблеми сучасної психології. 2013. № 2. С. 20-25. 
For example, Leontiev D.A. has created a model in which happiness is viewed from the point of self-regulation as a feedback phenomenon, as an experience of combining desired with actual ${ }^{4}$. Qualitative features of happiness are determined by the characteristics of personality goals.

In accordance with D.A. Leontiev there are two kinds of happiness: normative or happiness-minimum and eudemonic or happiness-maximum. Happiness-minimum can be achieved through the satisfaction of basic needs, and happiness-maximum - through the formation and achievement of personal-conscious goals, the realization of individual existential needs.

Thus, it is clear that Leontiev's concept can be attributed to the target direction, which focuses on the ultimate goal. In this approach one can experience and go through happiness-maximum, as a result of achieving existential goals and implementing the senses.

Next factor affecting life satisfaction is the availability of work, with not so much the fact of work or material incentives, but the psychological aspects of work, such as diversity and independence of work, its awareness, social value, emotional background, nature of the relationships with colleagues and bosses.

In addition to work, there is another factor such as leisure-time (handicraft, watching the media, physical and sports activities, visiting historical sites, museums, exhibitions, zoos; traveling to the city, visiting cafes, restaurants, dancing clubs, etc.). This factor is more important than work and it can be explained by the availability of space for activities related to inner motivation, enjoyment of communication, reinforcing the sense of identity, the availability of opportunities for exercise and rest.

The next factor is health.

Health is a state of complete physical, spiritual (mental) and social well-being, not just the absence of illnesses and physical defects. Physical health also reflects the person's condition which is driven by the normal functioning of all his or her physical organs and systems, a sense of satisfaction and well-being.

The best definition of mental health is given by the World Health Organization, according to which it is a state of well-being, in which a person can realize his or her own potential, cope with ordinary life difficulties, work productively and contribute to society. Therefore, it can be assumed that physical health refers to the normal physical functioning of the human body, and that mental health is related to the normal functioning of mental processes and the functioning of the person in general. The concept of mental health refers to the full psychological functioning of the individual.

\footnotetext{
4 Леонтьев Д.А. Личностное в личности: личностный потенциал как основа самодетерминации // Ученые записки кафедры общей психологии МГУ им. М.В. Ломоносова. Вып. 1 / Под ред. Б.С. Братуся, Д.А. Леонтьева. Москва: Смысл, 2002. С. 56-65.
} 
M. Arhail also identifies a special group of factors that he called personality. They include self-respect, self-esteem, extraversion and life awareness.

Thus, according to M. Arhail factors important for life satisfaction in general and for happiness are having close social ties, job satisfaction, health, having free time for leisure, personal qualities, positive emotions. Material security is less significant. And factors that do not affect life satisfaction are age and gender.

M. Seligman created his formula for happiness $(\mathrm{H}): \mathrm{H}=\mathrm{S}+\mathrm{C}+\mathrm{V}$,

Happiness $=$ ones set range + external circumstances + voluntary control,

where $\mathrm{S}$ is the ones set range, the genetically predetermined level of happiness that remains relatively stable throughout life and to which we return after most significant events in our lives. It defines happiness at about $50 \%$.

$\mathrm{C}$ is the external circumstances (family, children, religion, daily activities. It defines happiness at $10 \%$.

$\mathrm{V}$ is factors that lend themselves to voluntary control, they are conscious actions and actions that require efforts and which individuals can choose for themselves. It defines happiness at about $40 \%$.

M. Seligman introduces the notion of a pleasant life, a good life and a conscious life into the model of genuine happiness, trying to define what wellbeing is. A pleasant life seeks positive emotions. A parallel can be seen between it and hedonistic well-being. In a good life, a person uses his or her strengths for rewards in the form of activities that he or she enjoys, which can be called "flow". This term was introduced by M. Csikszentmihalyi, and it means a vivid, exciting experience that accompanies the activity that the person is focused on.

From M. Csikszentmihalyi point of view, if a person is able to organize his/her consciousness so that the flow state occurs as often as possible, the quality of his/her life will be improved. When a person is in a state of flow, he or she can control his/her psychic energy, and all his/her actions contribute to the orderly of consciousness.

"Happiness is a state that everyone has to prepare for, cultivate, and maintain inside" . People who have learned to control their worries can influence their quality of life themselves. That is how each of us can only become a happy person.

Happiness cannot be found if one even deliberately set such a goal. From M. Csikszentmihalyi perspective, we find happiness when we are completely immersed in the little things that make up our lives. But not when we try to look for it.

5 Чиксентмихайи М. Поток: Психология оптимальтного переживания. Под ред. Д. Леонтьева. : Москва: Альпина Паблишер.2018. 461 с. 
V. Frankl, almost affirming M. Csikszentmihalyi's opinion, said in his famous book "Man's Search of Meaning" that the more a person focuses on the search for success, the more difficult it is to find. Because success, as well as happiness, is a side effect of a person's focus on something more than he or she is ${ }^{6}$.

A conscious life is to use one's strengths when one is serving something that is greater and higher than one's self ${ }^{7}$.

In addition to these factors, another important factor in life satisfaction is the quality of life of the individual. The notion of a quality life is first and foremost related to measuring human well-being. This term is widely used in the social sciences as a category that reflects the quality of human life and the degree of satisfaction of his/her needs.

Quality of life can also be defined as the degree of comfort of a person, both in his or her inner world and within his/her society. Quality of life criteria are used to assess people's living standards when developing different health and social programs for different population groups.

Quality of life is a multifactorial term and researchers are mainly interested not in the overall quality of life rate itself, but in its components: human satisfaction with the degree of physical (activity, mobility, self-care), psychological (emotional background, including feelings of happiness or suffering), social (possibility of participation in social activities, contacts, disabilities for health reasons in terms of study, work, rest) and spiritual wellbeing; general perception of one's health and well-being.

The definition formulated by the World Health Organization discloses the essence of quality of life most fully and accurately. According to it quality of life is individual's perception of their position in life including physical, mental and social well-being, depending on the quality of the environment in which they live, as well as the degree of satisfaction with a particular standard of living and other components of psychological comfort ${ }^{8}$. That is, the essence of quality of life lies in its socio-psychological nature, which is manifested in a person's perception of his/her own satisfaction in different areas of his life and its arrangement, which are related to the level of his/her needs.

Quality of life is evaluated according to the following parameters:

- Physical - well-being, energy, fatigue, workability, sleep and rest;

- Psychological - self-esteem, cognitive processes, concentration, positive emotions, negative experiences, mindset, self-regulation;

\footnotetext{
${ }^{6}$ Франкл В. Человек в поисках смысла. Санкт-Питербург: Биг- Пресс.2012. 204 с.

${ }^{7}$ Селигман Мартин Э.П. Новая позитивная психология. Москва: София 2006, 347 с.

${ }^{8}$ Бонивелл, И. Ключи к благополучию. Что может позитивная психология / пер. с англ. М. Бабичевой. Москва:Время, 2009. 192 с.
} 
- Degree of independence - daily activity, workability, dependence on medicines and treatment;

- Life in society - daily activity, social relations, friendships, social significance, professionalism;

- Environment - housing and life, safety, leisure, access to information, ecology (climate, pollution, overpopulation); spirituality and personal beliefs ${ }^{9}$.

A quality of life is first of all related to measuring one's well-being. This term is widely used in many sciences as a category that reflects the quality of life conditions of a person, the degree of satisfaction of his needs.

Quality of life is the degree of comfort of a person, both in his inner world and in society in general.

When it comes to the categories of life satisfaction, needs, happiness, quality of life, psychologists mention repeatedly A. Maslow's concept of needs. According to it, the easier it is for a person to fulfill his needs, or the more and better they are realized, the higher the quality of his/her life is. The level of well-being can only be determined by the individual, depending on whether he or she believes that their needs are being met. A person can evaluate their quality of life through a sense of happiness, health, a sense of age, an awareness of their own prospects for life, etc.

However, there is a difference between the concepts of "quality of life" and "feeling of quality of life". Quality of life refers to the objective dimension, and the feeling of quality of life refers to the subjective. Quality of life is conditioned by the external conditions and objective reality of the individual, which become the source of life experience. While the feeling of quality of life is determined by the subjective attitude to the surrounding reality, which is formed by the emotions and feelings of a person.

Therefore, a feeling of quality of life is subjective in its content and it is often combined with a feeling of happiness and well-being. Most often, happiness means relationships based on trust and love, empathy, understanding and focusing on the other person, etc.

A person's quality of life brings together the most important areas of his or her life, the satisfaction of which may indicate a positive or high quality of life, and a negative perception of one's life may indicate a negative quality or standard of living. Positive quality of life is associated with the individual's experience of feeling satisfied with life, happiness, job satisfaction, well-being and other.

9 Віговська О. Якість життя особистості: теоретико-емпіричні доробки сучасної психології. Освіта регіону. Політологія. Психологія. Комунікації. Київ: Університет «Україна». 2013. № 2(32). С. 161-165. 
R.M. Shamionov believes that the main function of psychological wellbeing is to create a dynamic balance between the individual and the world around him $/$ her $^{10}$.

Among the most frequently used techniques for measuring overall life satisfaction according to M. Arhail ${ }^{11}$, I.A. Dzhydarian ${ }^{12}$ and E. Diner ${ }^{13}$ can be named at least two (the use of which is also related to an important issue around which discussions are under way over the last 40 years - how many indicators can reflect the satisfaction of life relevantly) based on the use of ordinal scales.

One of them is the Satisfaction With Life Scale (SWLS), provided by Diener and colleagues and it suggests to respondents to indicate the degree of agreement with five alternatives using a seven-point scale: my life is close to perfect; the conditions of my life are excellent; I am satisfied with my life; I have gotten the important things I want in life; if I could live my life over, I would change almost nothing.

Both criteria based on several indicators (eg, Diener's and colleagues scale) and on one parameter (eg the Campbell's and co-authors scale) ${ }^{14}$ are considered as adequate for assessing overall life satisfaction. At the same time, they often use only one question about overall life satisfaction, substantively similar to the one asked by Campbell and colleagues.

Thus, the World Values Survey asks the only question: "Considering everything, how satisfied are you with your life these days?" The Gallup Center's one: "In general, how satisfied or dissatisfied are you with how things are going in your life today? Would you say that you are very satisfied, to some extent satisfied, to some extent dissatisfied or very dissatisfied?"

\section{Main characteristics of the individual's subjective well-being}

The idea of life satisfaction is a multifactorial concept. Most often it is associated with the factor of subjective well-being of the individual.

Subjective well-being is a cognitive-affective assessment of a current situation whether it is prosperous or disadvantaged ${ }^{15}$.

10 Шамионов Р.М. Психология субъективного благополучия личности Саратов: Изд-во Саратовского университета, 2004. 174 с.

${ }^{11}$ Аргайл М. Психология счастья. Изд.2-е. Санкт-Петербург: Питер, 2003. 332 с.,

12 Джидарьян И.А. Счастье в представлениях обыденного сознания. Психологический журнал. 2000. Т. 21. № 2. С. 40-48.

${ }^{13}$ Diener E., Emmons R.A., Larsen R.J., Griffin S. The Satisfaction with Life Scale. Journal of Personality Assessment. 1985, 49(1). C. 71-75.

14 Віговська О. Якість життя особистості: теоретико-емпіричні доробки сучасної психології. Освіта регіону. Політологія. Психологія. Комунікації. Київ: Університет «Україна». 2013. № 2(32). С. 161-165.

${ }^{15}$ Селигман Мартин Э.П. Новая позитивная психология. Москва: София. 2006, 347 с. 
The study of subjective well-being began in the 1960s of XX century within the humanistic and positive psychology. Researchers such as M. Arhail, N. Bradburn, E. Diener, A. Campbell, P. Convers, K. Riff, V. Rogers, M. Seligman, and others analyzed both objective, external living conditions as well as various psychological characteristics that affect the subjective well-being of the individual. Their studies have shown that despite the importance of external factors (income, education, health, family, work, etc.), personal characteristics are even more significant in the sense of subjective well-being.

Subjective well-being of the individual is a complex socio-psychological phenomenon that includes emotional, cognitive and conative components and forms during social-psychological activity in the system of individual's real attitude to the objects of environment. It is based on socio-psychological attitudes, values and strategies of behavior.

The cognitive component of subjective well-being arises from a holistic relatively non-contradictory picture of the subject's world along with understanding of his or her current life situation. Controversial information brings dissonance in the cognitive sphere of personality, perception of the situation as uncertain, informational or sensory deprivation.

The emotional component of subjective well-being is manifested as an experience that combines feelings that are conditioned by the successful (or unsuccessful) functioning of all individual's sides. Disharmony in any area of the personality also causes emotional discomfort.

In order to understand subjective well-being, it is necessary to determine the existence of two approaches and, accordingly, of two types of well-being. They are hedonistic and eudemistic. Hedonistic focuses on the understanding of life as an intrinsic value, daily life stands above meaning, it is significant with its ordinary pleasures and benefits and the ability to meet its needs. The eudaimonist direction understands the meaning of life above everyday life and the central concept is the level of self-realization of the individual and the person's awareness of his life.

In the study of subjective well-being particularly important is the conformity of current needs to an ability to meet them. Thus, the level of wellbeing corresponds to meeting the needs of different levels, such as vital, social, ideal needs of understanding the world and one's place in it, both by appropriation of already existing cultural values and by the discovery of a completely new ones ${ }^{16}$.

16 Курова А. В. Соціально-психологічний аналіз суб'єктивного благополуччя особистості. Вісник ОНУ ім. І. І. Мечникова. Психологія. 2015. Т. 20. Вип. 2 (36). Ч. 1. C. 23-28. 
This conception and understanding of subjective well-being is fully in line with A. Maslow's concept, which states that the degree of individual's selfactualization corresponds to the hierarchical structure of the sphere of needs ${ }^{17}$.

According to A. Maslow, human needs are arranged in a hierarchy. At the heart of this hierarchy is the principle that the emergence of one need precedes the satisfaction of another, more urgent ones. There are five such goals or needs of the individual: physiological needs, security needs, love needs, self-esteem needs, and self-actualization needs (self-improvement, selfdevelopment). The hierarchical nature of these needs is determined by the fact that "the dominant goal monopolizes consciousness and in a way stimulates and organizes the various body's abilities which are necessary to achieve it.

Therefore, needs that are less relevant to the individual are minimized or neglected.

A. Maslow believed that a person who was able to reach the top in his or her needs and motivational intentions is an already formed personality, a selfactualizing person, that is, satisfied with his/her life ${ }^{18}$.

The ratio between how well a person satisfies his or her needs and how he/she spends his/her life resources to meet those needs is summarized in how a person feels and assesses his/her level of satisfaction with life. Life satisfaction acts as an assessment of all living conditions, formed on the basis of a comparison of individual's aspirations and actual achievements ${ }^{19}$.

Subjective well-being is a subjective reflection of external conditions, which captures the comfort or discomfort of living standards and is formed by comparing oneself to the real conditions and circumstances of life: acceptance or rejection of these circumstances and the presence or absence of proper way of self-realization under these conditions.

In turn, life satisfaction in general acts as a function of satisfaction of all real human needs.

Andrews and Whitney identified three components of subjective wellbeing in 1976: life satisfaction, positive emotions and negative emotions. Subjective well-being will be higher, the greater a person's positive emotions, the less negative emotions and the greater the satisfaction with one's life is, which is not a purely emotional appraisal but involves cognitive judgment.

${ }^{17}$ Мардасова Т.А. Потенциал концепции зависимой личности: вопросы современной аддиктологии Человек в трудной жизненной ситуачии: материалы Всероссийской научнопрактической конференции с международным участием (Барнаул, 28 ноября 2014 г.). Барнаул: Изд-во Алтайского.ун-та, 2015. С. 182-186.

${ }^{18}$ Маслоу А. Мотивация и личность. Санкт-Петербург: Питер, 2008. 308 с.

${ }^{19}$ Diener E., Emmons R.A., Larsen R.J., Griffin S. The Satisfaction with Life Scale. Journal of Personality Assessment. 1985. № 49(1). C. 71-75. 
Choosing an adequate option for fixing a person's subjective assessment of the level/degree of overall satisfaction/dissatisfaction with how his or her life is currently working out draws us to a review of the approaches to life satisfaction assessment traditionally developed in the context of quality of life research. Identifying the degree of social adaptability of the individual here seems to be in some ways an isomorphic problem to the study of quality of life - in aspects of a subjectively determined level of well-being(subjective well-being vs. ill-being).

For example, M. Arhail defines subjective well-being as the subjective self-esteem of how good a person considers his life, and R. Vingoven claims that subjective well-being is conditioned by the satisfaction of basic, universal human needs ${ }^{20}$.

$\mathrm{K}$. Ryff approached this issue in terms of positive personality functioning, proposes a model of well-being that includes six elements such as SelfAcceptance, Positive Relations, Personal Growth, Environmental Mastery Personal Growth, Autonomy, and Purpose in Life.

Self-acceptance reflects a positive self-esteem of yourself and your life as a whole, awareness and acceptance of not only your positive qualities, but also your shortcomings. While the feeling of dissatisfaction with oneself is the opposite of self-acceptance and is characterized by the rejection of certain qualities, dissatisfaction with the past and life in general.

Positive relationships with other people include the ability to sympathize, to be open to communication, the skills to establish and maintain contact with people, the desire and ability to be flexible in dealing with others, the ability to compromise. The opposite pole is loneliness, inability to establish and maintain relationships based on trust, unwillingness to seek and compromise, seclusion, secrecy.

Personal growth implies a desire for development, learning and perception of the new things along with sense of self-development and progress in life. Personal growth is a tendency to improve one's abilities to develop and retain one's personality. The essence of personal growth is finding yourself and your course of life. By the way, K. Rogers believed that if there are necessary conditions, then the person actualizes the process of self-development, the natural consequence of which will be changes in the direction of his personal maturity. It is these changes - their content, focus, dynamics - that suggest the process of personal growth and may be its criteria.

The main psychological content of personal growth is liberation, finding oneself and one's way of life, self-actualization. The interaction of the individual with his/her personal world as a whole is no less (and in many

\footnotetext{
${ }^{20}$ Аргайл М. Психология счастья. Изд. 2-е. Санкт-Петербург.: Питер, 2003. 332 с.
} 
cases more) significant than with the external world. It is also essential for a person to recognize and respect other people's inner world. That is, fullfledged personal growth is possible only if the intrapersonality is not suppressed by the interpersonal personality, and if there is no neglect but cooperation between the individual, his inner and outer worlds.

If personal growth is not happening, then it results in a feeling of boredom, stagnation, lack of faith in their abilities and opportunities for change as well as to master new skills. The lack of progressive personal development may indicate a general decrease in interest in life.

Environmental management is defined by the availability of qualities that determine the successful mastery of different activities, the ability to achieve what is desired, overcome the difficulties in achieving ones own goals. In case of the absence of this characteristic, the person feels his/her own powerlessness, incompetence, inability to change or improve something in order to get what one wants.

Autonomy means the ability to be independent, to have and express freely one's own opinion, to think and to behave outside the box, the ability and freedom not to follow the crowd and not be guided by the preferences and opinions of the majority.

At the opposite pole, where autonomy is not formed, one feels conformism, dependence on personal and social relations.

$\mathrm{K}$. Ryff believes that all of these components are substantively related to many theories and psychological approaches that consider positive personality functioning. For example, self-acceptance correlates with the terms of "selfrespect" and "self-acceptance", which were developed in the concepts of K. Rogers and A. Maslow, G. Allport, and M. Jahoda.

According to G. Allport, self-respect is a feeling of pride that a child feels when he or she does something on their own. Self-esteem depends on the child's successful implementation of any tasks. But quite often parents block the development of a child's self-worth in childhood because they believe that they know better how and what to do.

The child feels such behavior of adults as an encroachment on their integrity and independence. And if the parents continue to block these aspirations of the child, it will form a feeling of guilt and annoyance with which they will go through life.

At the age of four to five, self-respect can turn into competitiveness and be felt as a victory.

K. Ryff correlates such a psychological component of well-being as "selfacceptance" not only with the concepts of self-respect and self-acceptance that have been proposed by A. Maslow, K. Rogers, G. Allport, and M. Jahoda. It also includes an individual's recognition of his or her merits, advantages 
and disadvantages, a positive assessment of a person's own past, which E. Erikson described as part of the ego-integration process.

$\mathrm{K}$. Ryff also notes in his work that well-being is a broader concept than feeling of life satisfaction ${ }^{21}$.

I. Horbal gives very successful definition of subjective well-being, she defines it as a person's dynamic cognitive-emotional assessment of quality of their own life in general and of its individual spheres, which is formed on the basis of objective factors, perceived and mastered by the individual according to their individual-typological features.

Subjective well-being is an assessment of a person's own personality and life in general, which depends, on the one hand, on them and on their personal characteristics, on the other hand, on the realities of their life $\mathrm{e}^{22}$. Thus, psychological well-being can be defined as the result of a complex interaction of external and internal factors that influence person's perception and assessment of his/her own life.

According to A. Kurova subjective well-being of the person is a complex socio-psychological formation that contains emotional, cognitive and conative components that are formed in the process of socio-psychological activity, in the system of real relationships of the individual to the objects of environmental reality and which are developed on the basis of socialpsychological attitudes, values and strategies of behavior. Internal (values and semantic formation of personality, social and psychological attitudes, strategies of behavior) and external (socialization conditions) factors influence the subjective well-being of the individual ${ }^{23}$.

There are such characteristics of subjective well-being:

- Subjectivity - subjective individual well-being connected to personal experience.

- Positivity of dimension-reliance on the positive aspects, not on the absence of negative components.

- Global dimension - subjective well-being includes a global assessment of all aspects of life between the weeks to decades.

${ }^{21}$ Ryff C., Keyes C. L. The Structure of Psychological Well-Being Revisited. Journal of Personality and Social Psychology. 1995. Vol. 69. № 4. P. 719-727.

22 Горбаль І.С. Відчуття суб'єктивного благополуччя як передумова та втілення психологічного здоров'я особистості. Науковий вісник Львівського державного університету внутрішніх справ. Серія «Психологічна»: зб. наук. праць / за ред. М.М. Цимбалюк. Вип. 2 (2). Львів: ЛДУВС, 2012. С. 293-303.

23 Курова А. В. Соціально-психологічний аналіз суб'єктивного благополуччя особистості. Вісник ОНУ ім. І. І. Мечникова. Психологія. 2015. Т. 20. Вип. 2 (36). Ч. 1. C. $23-28$. 
The concept of satisfaction and well-being of a person consists of subjective emotional attitude to the substantive side of events and phenomena. Internal comfort, spiritual development, satisfaction with the quality of life makes one feel happy. This makes the subjective well-being of the individual emotionally positive.

The subjective well-being of a person appears as a result of socialization process that determines individual's qualities, specificity and diversity of their life, which contributes or does not contribute to the their well-being.

The feeling of subjective well-being does not always coincide with the objective well-being of the individual, which is estimated at the social criteria of one's personal achievements, structure and orientation of personality, behavior and activity, as well as at the contribution made by each person, group or society.

The objective well-being of the individual has a broader meaning. It may not be connected with a feeling of personal well-being of particular individual. For example, a person with a university degree, a good job, a normal wage and good living conditions can feel unhappy. People consider $\mathrm{him} / \mathrm{her}$ to be a happy person, but they are not satisfied with their life at all.

However, the subjective well-being of the individual is felt by each particular personality. Sometimes subjective well-being cannot be explained in specific terms - a person may simply feel happy.

Subjective well-being is determined by the person's system of ideas about themselves, their life, relationships, health, etc.

Boniwell defines the formula of well-being:

Subjective well-being $=$ life satisfaction + affect.

Life satisfaction in this formula reflects a person's assessment of his or her own life. A person is satisfied when there is almost no gap between the current state of affairs and what they considers to be the ideal situation or one that they deserve. Dissatisfaction, in turn, is the result of a significant gap between what is given and the ideal. Dissatisfaction can also arise from comparing oneself to other people.

Affect is the emotional side, the positive and negative emotions and emotional states connected with daily experiences ${ }^{24}$.

Today, in positive psychology, there are several factors that correlate or do not correlate with subjective well-being. Factors such as optimism, extraversion, social ties, marriage, interesting work, religion and spirituality, leisure, good sleep and exercise, social status and subjective health are significantly correlated with subjective well-being.

${ }^{24}$ Бонивелл, И. Ключи к благополучию. Что может позитивная психология / Пер. с англ. М. Бабичевой. Москва: Время. 2009. 192 с. 
One of the first studies of subjective well-being was the N.M. Bradburn's research. In the first stage of the study, a description of a happy person of any gender and intelligence was obtained: young, healthy, well educated, with good earnings, extraversion, optimistic, carefree and religious. He/she is married, has a high self-esteem, fighting spirit and modest aspirations. Therefore, it was suggested not to speak of real well-being, but to use the term happiness as "what is declared" or "what is acknowledged".

This can be explained by the fact that subjective well-being is assessed solely by the individuals themselves in terms of their values and goals. As they are always unique, there can be no universal well-being structure for everybody. One can only explore the factors that influence this feeling of happiness and satisfaction.

\section{CONCLUSIONS}

The concept of life satisfaction is complex and delicate. It is connected with the concepts of subjective well-being, happiness, standard and quality of life, etc.

It is life satisfaction that is a real possibility for self-preservation of the individual, because it is a sign of the psychological well-being of the person.

Life satisfaction is a complex dynamic socio-psychological phenomenon, consisting of cognitive and emotional-volitional processes and characterized by a subjective emotional-evaluative attitude. Life satisfaction has a motivating effect because it facilitates the action, search and management of external and internal objects.

There are many factors that influence and shape life satisfaction. Most often, they can be divided into objective and subjective. Objective factors include: socio-economic, marital status, health, age and social relations.

Subjective factors include: the ratio of level of achievements and aspirations, consistency in achieving life goals and interest in life, internal locus of control, subjective life position, distance strategy and problemsolving strategy in difficult life circumstances, such personality characteristics as extraversion and optimism.

E. Dinar identified the link between subjective well-being and internal factors. For example, he found that personal traits combine from 40 to $50 \%$ of changes in subjective well-being. Therefore, it is possible that happiness can be considered as a personality trait that acts as a tendency to feel certain positive or negative emotions.

At the same time, social and cultural attitudes play a significant role in evaluating one's life. Psychological features of cultural values, traditional family values, patterns of desired life, traditions and social attitude to 
happiness, perception of a person while happy or unhappy, the components of a traditional happy life - all these factors influence the level of individual imagination and awareness of one's own life. This list can also be extended by the need to analyze the link between one's feeling of life satisfaction and religious attitudes that also form one's understanding and awareness of one's happiness and quality of life at the archetypal level.

If person thinks that life satisfaction is desirable, then one uses positive information when analyzing one's life. If happiness is an insignificant value in society, then the negative sides are given more attention when analyzing one's life. This in turn may reduce the cognitive assessment of one's life.

In the theory of self-determination represented by E. Deci and R. Ryan, it is believed that there are three main needs of the individual: autonomy, competence and connection with other people. Meeting these needs is important for a person's feeling of well-being and integrity. Thus, understanding of well-being is closer to the concept of the full functioning of the individual than to the result of achieving desires.

Life satisfaction can be investigated through certain criteria and components, but their quantity is undetermined and their research remains a topical and complex task of psychology.

\section{SUMMARY}

The article provides a detailed analysis of the psychological phenomenon of life satisfaction along with the factors that shape it and relate to it.

Life satisfaction is such an integrative concept that it may combine a number of criteria and indice. When analyzing life satisfaction of an individual, it is necessary to study the indicators of their subjective wellbeing, the degree of satisfaction of their needs as well as feeling happy or unhappy, etc. It is associated with an understanding of the full functioning of the individual, their self-determination and realization in life.

When defining life satisfaction criteria, it's common practice to refer to A. Maslow's concept of needs, as well as analyzes the term of quality of life and the person's sense of subjective and objective aspects of quality of life. Therefore, it can be assumed that in the study of personality satisfaction with their life, the psychologist will have to analyze its objective and subjective aspects, which reflect on the awareness of individual's life as satisfying, happy, or vice versa.

The study of life satisfaction is essential in present day conditions, because it gives an opportunity to understand the state of psychological health and well-being of an individual. 


\section{REFERENCES}

1. Аргайл М. Психология счастья. Изд 2-е. Санкт-Петербург : Питер, 2003. 332 c.

2. Джидарьян И.А. Счастье в представлениях обыденного сознания. Психологический журнал. 2000. Т. 21. № 2. С. 40-48.

3. Егорова М.С., Ситникова М.А., Паршикова О.В. Адаптация Короткого опросника Темной триады. Психологические исследования. 2015. T. 8. № 43. C. 15-21.

4. Вірна Ж.П. Адаптаційний профіль задоволеності життям особистості. Проблеми сучасної психології. 2013. № 2. С. 20-25.

5. Леонтьев Д.А. Личностное в личности: личностный потенциал как основа самодетерминации. Ученые записки кафедры общей психологии МГУ им. М.В. Ломоносова. Вып. 1 / под ред. Б.С. Братуся, Д.А. Леонтьева. Москва : Смысл, 2002. С. 56-65.

6. Чиксентмихайи М. Поток: Психология оптимального переживания / под ред. Д. Леонтьева. Москва : Альпина Паблишер. 2018. $461 \mathrm{c}$.

7. Франкл В. Человек в поисках смысла. Санкт-Петербург : БигПресc. 2012. 204 c.

8. Селигман Мартин Э.П. Новая позитивная психология. Москва : София, 2006, $347 \mathrm{c.}$

9. Бонивелл И. Ключи к благополучию. Что может позитивная психология / пер. с англ. М. Бабичевой. Москва : Время, 2009. 192 с.

10. Віговська О. Якість життя особистості: теоретико-емпіричні доробки сучасної психології. Освіта регіону. Політологія. Психологія. Комунікації. Київ : Університет “Україна”. 2013. № 2 (32). С. 161-165.

11. Шамионов Р.M. Психология субъективного благополучия личности. Саратов : Изд-во Саратовского ун-та, 2004. 174 с.

12. Diener E., Emmons R.A., Larsen R.J., Griffin S. The Satisfaction with Life Scale. Journal of Personality Assessment. 1985. № 49 (1). C. 71-75.

13. Курова А.В. Соціально-психологічний аналіз суб'єктивного благополуччя особистості. Вісник ОНУ ім. I. І. Мечникова. Психологія. 2015. Т. 20. Вип. 2 (36). Ч. 1. С. 23-28.

14. Мардасова Т.А. Потенциал концепции зависимой личности: вопросы современной аддиктологии. Человек в трудной жизненной ситуации: материалы Всероссийской научно-практической конференции с международным участием (Барнаул, 28 ноября 2014 г.). Барнаул : Изд-во Алтайского ун-та, 2015. С. 182-186.

15. Маслоу А. Мотивация и личность. Санкт-Петербург : Питер, 2008. $308 \mathrm{c}$. 
16. Ryff C., Keyes C.L. The Structure of Psychological Well-Being Revisited. Journal of Personality and Social Psychology. 1995. Vol. 69. № 4. P. 719-727.

17. Горбаль I.C. Відчуття суб'єктивного благополуччя як передумова та втілення психологічного здоров'я особистості. Науковий вісник Львівського державного університету внутрішніх справ. Серія "Психологічна" : зб. наук. праць / за ред. М.М. Цимбалюк. Вип. 2 (2). Львів : ЛДУВС, 2012. С. 293-303.

\section{Information about the author:} Skripachenko T. V., $\mathrm{Ph} . \mathrm{D}$ in Psychology, Department of Psychology, Associate Professor,

Zaporizhzhia National University 66, Zhukovskoho str., Zaporizhzhia, 69600, Ukraine 